\title{
Produksi Protein Total dan Kecernaan Protein Daun Kelor Secara In Vitro
}

\author{
Production of Total Protein and In Vitro Protein Digestibility of Moringa Leaf \\ Sumadi, A. Subrata dan Sutrisno \\ Fakultas Peternakan dan Pertanian Universitas Diponegoro \\ Tembalang 50275, Semarang, Indonesia \\ Koresponden e-mail : agung.subrata42@gmail.com
}

\begin{abstract}
This researchwasconducted at Feed and Nutrition Laboratory, Faculty of Animal and Agriculture, Diponegoro University, Semarang from October to November 2016. The study aims to examine the total protein production and protein digestibility of Moringa leaf in vitro. The study was done in three stages: preparation, in vitro test and analysis. The material used of rumen goat crossbreed etawa (PE), moringa leaf and leucaena leaf as a comparison T-test. Productiontotal protein was analyzed by Tilley and Terry method 1, while protein digestibility was analyzed using Tilley and Terry 2 method.Protein analysis using Kjeldahl method 1883 according to (AOAC, 2005). The results showed that total production of total Moringa leaf protein was not different $(\mathrm{P}>0.05)$ compared with lamtoro leaf $(377,60 \mathrm{mg} / \mathrm{g}$ vs 478,92 mg/g). The digestibility of Moringa leaf protein was significantly $(\mathrm{P}<0.05)$ higher compared with lamtoro leaf $(64.29 \%$ vs $50.74 \%)$. The conclusion of this research is that Moringa leaf has good quality as protein source of ruminant livestock because it possess high protein digestibility compared with leaf leucaena.
\end{abstract}

Key words: Kelor, in vitro, total protein production, protein.

\begin{abstract}
ABSTRAK
Penelitian dilaksanakan di Laboratorium Ilmu Nutrisi dan Pakan, Fakultas Peternakan dan Pertanian, Universitas Diponegoro, Semarang bulan Oktober-November 2016. Penelitian bertujuan untuk mengkaji produksi protein total dan kecernaan protein dari daun kelor secara in vitro. Penelitian dilakukan dalam tiga tahap yaitu persiapan, uji in vitro dan analisis. Materi yang digunakan yaitu cairan rumen kambing peranakan etawa (PE), daun kelor dan daun lamtoro yang digunakan sebagai pembanding uji T-test. Produksi protein total di analisis dengan metode Tilley dan Terry tahap 1, sedangkan kecernaan protein di analisis menggunakan metode Tilley dan Terry 2 tahap. Analisis protein menggunakan metode Kjeldhal 1883 menurut (AOAC, 2005). Hasil penelitian menunjukan bahwa jumlah produksi protein total daun kelor tidak berbeda $(\mathrm{p} \geq 0,05)$ dibandingkan dengan daun lamtoro $(377,60 \mathrm{mg} / \mathrm{g}$ vs $478,92 \mathrm{mg} / \mathrm{g})$. Kecernaan protein daun kelor nyata lebih tinggi $(\mathrm{p} \leq 0,05)$ dibandingkan dengan daun lamtoro $(64,29 \%$ vs $50,74 \%)$. Simpulan dari hasil penelitian adalah daun kelor mempunyai kualitas yang baik dibandingkan daun lamtoro karena memiliki kecernaan yang tinggi pasca rumen.
\end{abstract}

Kata kunci: Kelor, in vitro, produksi protein total, protein.

\section{PENDAHULUAN}

Ternak ruminansia merupakan ternak yang memiliki saluran pencernaan yang khas, karena memiliki lambung majemuk yaitu rumen, retikulum, omasum dan abomasum. Ternak ruminansia mampu mencerna pakan yang memiliki kualitas rendah (kandungan serat yang tinggi) karena di dalam rumen ternak ruminansia terdapat mikroorganisme yang berfungsi memfermentasi serat pakan. Persyaratan sumber protein untuk ternak ruminansia antara lain: mampu menyediakan $\mathrm{N}$ bagi pertumbuhan mikrobia, tahan degradasi atau mampu menyediakan UDP yang tinggi, dan memiliki nilai hayati tinggi.

Daun kelor memiliki kandungan nutrisi yang cukup baik diantaranya protein kasar (PK) 26,43\%, lemak kasar (LK) 2,23\%, serat kasar (SK) 23,57\%, abu $6,77 \%$, bahan ekstrak tanpa nitogen (BETN) 52,25\%. Kandungan protein kasar dari daun kelor cukup tinggi sehingga baik untuk pakan ternak atau campuran penyusun complete feed. Kualitas protein 
ternak ruminansia dapat diukur dari kecernaannya, semakin tinggi kandungan protein pakan, semakin tinggi kecernaannya.

Protein total merupakan gabungan dari protein pakan yang lolos dari degradasi rumen dan protein mikrobia. Fungsi dari protein total yaitu untuk mengetahui berapa besarnya protein yang lolos dari degradasi rumen dan jumlah protein mikrobia yang masuk kesaluran pencernaan pasca rumen.

UDP (Undegraded Dietary Protein) adalah protein pakan yang lolos degradasi mikrobia rumen, atau protein pakan yang tahan terhadap serangan mikrobia di dalam rumen. Widyobroto et al. (2007) berpendapat bahwa UDP merupakan protein pakan yang tidak terdegradasi di dalam rumen, sehingga dapat langsung mengalami proses pencernaan enzimatis di dalam abomasum dan intestinum. Fungsi dari UDP yaitu untuk mengetahui seberapa besarnya protein pakan yang mampu lolos dari degradasi rumen.

Kecernaan protein kasar adalah total protein pakan yang diserap oleh tubuh dan tidak diekresikan dalam feses. Protein kasar tidak hanya mengandung protein saja tetapi juga mengandung nitrogen yang bukan berasal dari protein (non protein nitrogen). Non protein nitrogen merupakan nitrogen bukan dari senyawa protein yang bias berasal dari asam amino bebas, asam nukleat, amonia, danurea yang dapat diubah menjadi protein oleh mikrobia rumen. Kecernaan protein pada ternak ruminansia tergantung pada sifat bahan pakannya diantaranya memiliki sifat tahan degradasi di dalam rumen, bahan pakan mampu menyumbangkan proteinnya untuk pertumbuhan mikrobia rumen.

Penelitian ini bertujuan untuk mengetahui suplai protein total daun kelor dan kecernaan protein secara in vitro. Manfaat yang diharapkan dari penelitian ini adalah memberikan informasi berkaitan dengan potensi pemberian daun kelor terhadap suplai protein total dan kecernaan proteinnya secara in vitro. Hipotesis dari penelitian ini adalah semakin tinggi protein yang lolos dari degradasi rumen maka semakin tinggi kecernaan protein yang masuk pasca rumen.

\section{MATERI DAN METODE}

Tabel 1 merupakan formulasi ransum yang digunakan untuk pakan kambing berfistula. Materi yang digunakan dalam penelitan ini adalah daun kelor, daun lamtoro dan cairan rumen dari kambing Jawarandu betina berfistula berumur 12-18 bulan dengan bobot badan $31,25 \mathrm{~kg}$.

Tabel 1. Komposisi pakan kambing berfistula

\begin{tabular}{|c|c|c|c|c|c|}
\hline BahanPakan & Formula & PK bahan & PK pakan & TDN bahan & TDN pakan \\
\hline & ------ & & - & ----- & ---.- \\
\hline Gaplek & 1,1 & 5,33 & 0,06 & 74,58 & 0,82 \\
\hline Tetes & 1,0 & 0,66 & 0,01 & 75,01 & 0,75 \\
\hline Bungkil kedelai & 17,0 & 35,97 & 6,11 & 81,10 & 13,79 \\
\hline Bekatul & 10,7 & 9,70 & 1,04 & 67,48 & 7,22 \\
\hline Mineral & 0,2 & 0,00 & 0,00 & 0,00 & 0,00 \\
\hline Rumput gajah & 70,0 & 7,02 & 4,91 & 54,85 & 38,39 \\
\hline Jumlah & 100 & & 12,13 & & 60,97 \\
\hline
\end{tabular}


Uji produksi protein total secara in vitro menurut metode Tilley dan Terry (1963) tahap 1 (inkubasi 48 jam). Sampel residu setelah tahap 1 dihomogenkan, diambil $10 \mathrm{ml}$ selanjutnya ditambah TSA+SSA sebanyak $10 \mathrm{ml}$ dan diendapkan selama 4-5 jam. Setelah endapan itu disaring. Hasil penyaringan di oven pada suhu $105^{\circ} \mathrm{C}$ untuk mendapatkan bahan keringnya (BK). Kemudian residu hasil pengendapan di analisis protein dengan metode kjeldhal (1883) menurut AOAC (2005). Protein total dihitung dengan rumus : protein total $(\mathrm{mg} / \mathrm{g})=$

$$
\frac{(\mathrm{a}-\mathrm{b}) \times \mathrm{c} \times 14 \times 6,25}{\mathrm{~d}} \mathrm{mg} / \mathrm{g}
$$

Keterangan :

$\mathrm{a}=\mathrm{ml} \mathrm{HCl}$ titran

$\mathrm{b}=\mathrm{ml} \mathrm{HCl}$ blanko

$\mathrm{c}=\mathrm{N} \mathrm{HCl}$

$\mathrm{d}=$ Berat sampel endapan $(\mathrm{mg} / \mathrm{g})$ dari residu $10 \mathrm{ml}$.

Uji kecernaan protein dianalisis menggunakan metode Tilley dan Terry (1963) 2 tahap. Protein sampel dan protein residu di analisis dengan menggunakan metode kjeldhal menurut (AOAC, 2005) dengan rumus: $\%$ Kecernaan protein $=$

$$
\frac{\% \mathrm{PKS} \times \sum \mathrm{S}-\sum \mathrm{PK} \mathrm{R}}{\% \mathrm{PKS} \times \sum \mathrm{S}} \times 100 \%
$$

Keterangan:

$\% \mathrm{PK} \mathrm{S}=\%$ protein kasar sampel

$\sum \mathrm{S} \quad=$ jumlah sampel

$\sum \mathrm{PK} \mathrm{R}=$ jumlah protein kasar residu

Data di analisis menggunakan uji statistik paired T-Test dengan menggunakan program komputer SPSS versi 16.0, dengan syarat data berdistribusi normal. Normalitas data diuji menggunakan uji one sample KolmogorovSmirnov test.

\section{HASIL DAN PEMBAHASAN}

Berdasarkan Tabel 2 dibawah ini menunjukkan hasil penelitian mengenai produksi protein total dan kecernaan protein.

Tabel 2. Produksi protein total dan kecernaan protein

\begin{tabular}{lcc}
\hline $\begin{array}{c}\text { Bahan } \\
\text { pakan }\end{array}$ & $\begin{array}{c}\text { Produksi protein } \\
\text { total }(\mathrm{mg} / \mathrm{g})\end{array}$ & $\begin{array}{c}\text { Kecernaan } \\
\text { protein }(\%)\end{array}$ \\
\hline Kelor & 377,60 & $64,29^{\mathrm{a}}$ \\
Lamtoro & 478,92 & $50,74^{\mathrm{b}}$ \\
\hline
\end{tabular}

Keterangan: Superskrip ${ }^{\mathrm{a}, \mathrm{b}}$ yang berbeda pada kolom yang sama menunjukkan perbedaan yang nyata $(\mathrm{p} \leq$ $0,05)$.

\section{Produksi Protein Total}

Berdasarkan Tabel 2 menunjukkan bahwa produksi protein total daun kelor tidak berbeda $(\mathrm{p} \geq 0,05)$ dibandingkan produksi protein total daun lamtoro. Produksi protein total daun kelor adalah $377,61 \mathrm{mg} / \mathrm{g}$ sedangkan pada daun lamtoro yaitu 478,92 mg/g. Protein total merupakan protein yang dihasilkan dari bahanprotein bahan pakan yang tidak terdegradasi dan protein mikrobia. Sunarso (1984) menyatakan bahwa protein total adalah gabungan dari protein pakan yang lolos dari degradasi mikroba rumen dan protein mikrobia.

Persentase produksi protein total daun kelor dan daun lamtoro tidak berbeda dapat dipengaruhi oleh kandungan protein dari bahan pakan yang hampir sama dan aktivitas mikrobia yang sama karena menggunakan cairan rumen dari kambing yang sama. Protein total adalah gambaran dari protein pakan yang tidak terdegradasi di dalam rumen dan protein mikrobia yang merupakan gambaran protein yang tersedia 
untuk ternak ruminansia. Nilai protein total adalah nilai protein yang tersedia di organ pencernaan pasca rumen. Protein total memliki peranan yang sangat penting untuk ternak yaitu untuk mengetahui besarnya nilai protein yang lolos dari degradasi mikrobia rumen serta seberapa besar konsentrasi protein mikrobia yang ada didalam organ pencernaan pasca rumen.

\section{Kecernaan Protein}

Berdasarkan Tabel 2 dapat diketahui bahwa kecernaan protein pada daun kelor nyata $(\mathrm{P}<0,05)$ lebih tinggi dibandingkan dengan daun lamtoro. Kecernaan protein pada daun kelor adalah 64,29\% sedangkan pada daun lamtoro lebih rendah yaitu $50,74 \%$. Tingginya kecernaan protein daun kelor dapat dipengaruhi oleh perbedaan kandungan nutrien (protein atau bahan organik), tipe protein (struktur dan kelarutan protein), interaksi nutrien khususnya karbohidrat dalam beberapa pakan didalam rumen (Hermon, 2009).

Karena kandungan protein pakan yang hampir sama dan degradabilitas di dalam rumen hampir sama, tetapi daun kelor mempunyai sifat protein yang tidak mudah larut dibandingkan dengan daun lamtoro yang mudah larut dalam air sehingga kecernaan protein daun kelor menjadi tinggi dan efisien untuk ternak. Protein yang mudah larut menyebabkan mudah terdegrasi didalam rumen sehingga yang lolos hanya sedikit dibandingkan protein yang tidak mudah larut.

Kelarutan protein kasar yang tinggi dalam rumen merupakan penyebab tidak efisiennya pemanfaatan protein pakan yang dikonsumsi temak (Richard dan Van soest, 1977), sementara protein kasar yang tidak mudah larut air memiliki peluang yang besar untuk masuk ke dalam saluran cerna pascarumen, menyebabkan protein tersebut dapat dicerna secara enzimatis dan diserap secara efisien. Tingginya kecernaan protein pada daun kelor dapat dipengaruhi karena rendahnya kandungan serat kasar pada daun kelor yaitu $23,58 \%$ jika dibandingkan dengan daun lamtoro yaitu $30,63 \%$.

Kandungan serat kasar (SK) merupakan faktor pembatas lamanya waktu pencernaan sehingga mempengaruhi kecernaan dan akhirnya menurunkan tingkat kecernaannya. Hal ini sesuai dengan pendapat Tillman et al. (1998) menyatakan bahwa kecernaan bahan pakan akan menurun seiringan dengan peningkatan kadar serat kasar (SK), menyebabkan meningkatnya jumlah lignin yang mengikat sellulosa dan menyebabkan semakin turunnya nilai kecernaan.

Serat terbagi menjadi 2 bagian yaitu isi sel (acid detergent fiber) ADF dan dinding sel (neutral detergent fiber) NDF. Tingginya kecernaan protein daun kelor juga dapat dipengaruhi kandungan Neutral detergent fiber (NDF) yang rendah yaitu $22,75 \%$ jika dibandingkan dengan daun lamtoro yaitu $28,19 \%$.

Tingginya kandungan bahan pakan yang mengandung NDF yang tinggi mempunyai degradabilitas yang rendah karena kandungan NDF yang tinggi dalam pakan berkorelasi negatif dengan degradabilitas (National Research Council., 1984). Neutral detetergent fiber (NDF) atau dinding sel, merupakan bagian dari zat pakan yang tidak larut dalam detergent netral dan tersusun atas sellulosa, hemisellulosa, lignin, protein terikat serat dan silica. 


\section{KESIMPULAN}

Berdasarkan hasil penelitian dapat disimpulkan bahwa daun kelor memiliki kualitas yang baik karena memiliki kecernaan protein yang nyata lebih tinggi jika dibandingkan dengan daun lamtoro, sehingga protein mampu diserap oleh tubuh ternak.

\section{DAFTAR PUSTAKA}

Hermon. 2009. Indeks Sinkrosasi Pelepaasan N-Protein dan Energi dalam Ruen sebagai Basis Formulasi Ransum Ternak Ruminansia dengan Bahan Lokal. Disertasi. Sekolah Pasca Sarjana. Institut Pertanian Bogor, Bogor.

Horwitz, W. 2005. Association of Analytical Chemis: Animal Feed. Official methods of analysis (Edisi ke 17). AOAC. Gaithersburg, USA. 37-39.

National Research Council. 1984. Nutrient Requirements of Beef Cattle. $7^{\text {th }}$ Revised Edition. National Academic Science. Press, Washington DC.
Richard, G. and P. J. Van Soest. 1977. Protein solubility of ruminant feeds. Proc. the Cornell Nutrition Conference for Feed Manufacturers. pp. 91-98.

Sunarso. 1984. Mutu Protein Limbah Agro-Industri Ditinjau dari Kinetika Perombakannya oleh Mikrobia Rumen dan Potensinya dalam Menyediakan Protein bagi Pencernaan Pasca Rumen. Fakultas Pasca Sarjana Institut Pertanian Bogor, Bogor (Tesis Magister Pertanian).

Tillman, A.D., H. Hartadi, S. Reksohadiprojo, S. Prawirokusumo dan S. Lebdosoekojo. 1998. Ilmu Makanan Ternak Dasar. Cetakan ke6, Gadjah Mada University Press, Yogyakarta.

Widyobroto, B. P., Budhi, S. P. S., danAgus, A. 2007. Pengaruh Aras Undegraded Protein dan Energi terhadap Kinetik Fermentasi Rumen dan Sintesis Protein Mikroba pada Sapi Journal of the Indonesian Tropical Animal Agriculture. 32(3): 194-200. 